\title{
HBIM Development of A Brazilian Modern Architecture Icon: Glass House by Lina Bo Bardi
}

\author{
Ana Regina Mizrahy Cuperschmid ${ }^{1, *,+} \oplus$, Márcio Minto Fabricio ${ }^{2,+}$ and \\ Júlio César Franco Jr. ${ }^{2,+(\mathbb{D})}$ \\ 1 School of Civil Engineering and Architecture, Department of Architecture and Construction, University of \\ Campinas (UNICAMP), Campinas, SP 13083-889, Brazil \\ 2 Institute of Architecture and Urbanism, University of São Paulo (USP), São Carlos, SP 13566-590, Brazil \\ * Correspondence: cuper@unicamp.br; Tel.: +55-19-35212335 \\ + These authors contributed equally to this work.
}

Received: 16 June 2019; Accepted: 10 July 2019; Published: 12 July 2019

\begin{abstract}
Lina Bo Bardi's Glass House (Casa de Vidro) is a National Historic Landmark designed and built in the late 1940s in São Paulo, Brazil. The house is one of the symbols of modern Brazilian mid-century architecture. It is a historiographical reference of the history of modern architecture in Brazil. This article reports the experience, outcomes, challenges, benefits, and limitations of the Heritage Building Information Modeling (HBIM) process. The HBIM was developed for Lina's Glass House considering the following steps: modeling planning; data acquisition; model elaboration; recording of pathologies and damage; data management; documentation process. The HBIM developed includes historical information and geometric data from direct measurements, laser scanning, photographic survey, and pathologies documentation. The model allows professionals responsible for architecture, conservation, and restoration to access integrated information on projects and the current condition of the buildings easily and quickly. Good precision was achieved for important building elements, contributing to maintenance and restoration actions. This experience allowed the development of an integrated workflow of activities for collecting, processing, recording, and managing information that may serve as a baseline for future projects for the documentation of modernist buildings.
\end{abstract}

Keywords: Heritage Building Information Modeling; 3D modeling; Glass House; cultural heritage documentation; mid-century architecture; modernism

\section{Casa de Vidro: Glass House by Lina}

Casa de Vidro (Glass House) was designed by the architect Lina Bo Bardi in the late 1940s, in an area of 7000 sqm, in São Paulo, Brazil. The house was the object of dozens of publications in Brazil and abroad, being one of the symbols of modern Brazilian architecture of the 1950s. It is a historiographical reference of the history of modern architecture in Brazil.

The design is contemporary as other modernist glass houses, including the Eames house by Charles and Ray Eames in California, the Glass House by Philip Johnson in Connecticut, and Farnsworth House, a Mies van der Rohe design in Illinois; all designed with transparent facades integrating the interior of the residence with the landscape [1].

Casa de Vidro was the residence of Lina Bo Bardi and her husband, Pietro Maria Bardi, from its completion, in 1952, until their death, in the 1990s. The house was an important part of the life trajectory of this Italian couple who arrived in Brazil in 1946, remaining in the country for the rest of their lives [2]. 
Lina Bo Bardi's Casa de Vidro is recognized as Brazilian cultural heritage, being officially declared a federal, state, and municipal heritage since 1986, after the final pronouncement by Marco Antonio Tabet [2]. This official recognition of Casa de Vidro as cultural heritage was supported by the Bardi couple themselves.

Inside Casa de Vidro there is a rich collection of works of art, furniture, books, and documents. Outside of it, one can find vast gardens, a garage, a housekeeper's house, and an architecture studio.

As the terrain shows a very steep slope, the front side of Casa de Video was built with pilotis, with the back side resting on the ground. In contrast to the massive appearance of the back portion, the front side is an extremely lightbox built in reinforced concrete, glazed on three sides, and supported in seamless steel tubes. To emphasize the connection of the building with the sun and landscape, the large windows around the living area do not have guardrail of protection. The inner courtyard traverses the living area, providing cross-ventilation on warm days. In the middle of the living area lies an old tree, which was there prior to the construction. It is covered with flowers and emerges from the ground to become part of the environment [3].

This research was a partnership between the Lina Bo Bardi and Pietro Maria Bardi Institute (ILBPMB) and the Institute of Architecture and Urban Planning (IAU) of the University of São Paulo (USP), for the elaboration of "Casa de Vidro's Conservation and Management Plan", funded by the Getty Foundation under the grant "Keeping It Modern".

The research was developed over two years by a multidisciplinary team of about 20 professionals. In order to carry out the research, the professionals were organized in four teams: "Historical Research", "Structures, Materials, and Pathology", "Garden survey and management" and "Digital documentation and Heritage Building Information Modeling (HBIM)".

Casa de Vidro's Conservation and Management Plan required the teams to survey and inventory the main building, annex buildings, and the garden. The Heritage Building Information Modeling (HBIM) team gathered information from the other teams to build and feed the model, in addition to collecting on-site data.

From this perspective, one of the project's main challenge was, from the data embedded in the model, to extract a complete inventory of the building, with the pathologies and their treatments, using a single model that integrates teams and their methodologies of surveys and systematizations. The aim was to develop an inventory that could be fed continuously and used as a plan for the management of the architectural complex called Casa de Vidro.

This article reports the experience, outcomes, challenges, benefits, and limitations of the HBIM process applied to Lina Bo Bardi's Casa de Vidro. It also evaluates how current HBIM's processes and technologies allow for the documentation of the state of conservation and how it can assist the management of historic buildings.

\section{Heritage Building Information Modeling (HBIM)}

Building information modeling (BIM) stands out as project-oriented processes and technologies, including performance simulation and lifecycle management of buildings. Used for the design and management of new buildings, BIM also provides an opportunity for the documentation and conservation management of historic buildings [4]. BIM can be a useful tool for gathering information collected during the stages of survey, documentation, preservation, and analysis of historical data [4]., and, In addition, it can be used to evidence the inconsistencies between project documents and the existing building using coherent tridimensional models [5].

In cases when BIM is used for documenting, researching, conserving or managing assets of heritage buildings, it is called HBIM [6,7].

Initially, HBIM was defined as a system for modeling historical structures using laser scanner data [8]. Later, HBIM was characterized as "a novel solution whereby interactive parametric objects representing architectural elements are constructed from historical data, these elements (including 
detail behind the scan surface) are accurately mapped onto a point cloud or image-based survey" [9] (p. 89).

HBIM models allow to virtually combine consolidated information and integrate geometric and semantic data into a single database. HBIM seeks to gather multidisciplinary information in the form of parametric objects according to architectural treaties and rules [10]. Therefore, HBIM has great potential to be used for building management, including operation, maintenance, and document records [7].

HBIM makes it possible to share information among agents responsible for the preservation of architectural heritage, reducing the dispersion of information about the building, allowing greater efficiency in the documentation and planning of restoration actions [5,11].

HBIM models are relevant to studying, communicating, and explaining the technical and historical value of architectural heritage [12,13]. Attesting to this, [14], they emphasize the importance of understanding the value attributed to heritage to promote sustainable conservation in the long term.

Through HBIM it is possible to simulate and prevent risks [15], as well as to develop simulations about the structural system and the properties of the materials [16]. Additionally, the use of HBIM can favor the development of multiple options for intervention projects; the detection of conflicts between the proposed interventions and the existing building; analysis of historical phases of the building; the integration of diverse data (such as historical information, photographs, drawings, geospatial data, remote sensing data); the integration of intangible information (such as historic values associated with specific components or areas); interoperability (for data sharing); the possibility of integrating with other systems such as Geographic Information System (GIS), Computer-Aided Facility Management (CAFM) and databases [6].

\section{Development of Casa de Vidro's HBIM}

In the documentation process of Casa de Vidro, HBIM was chosen to maintain a reliable record for building management, to support future interventions, and to document the heritage asset in different stages: as it was designed and in its current state.

Several studies have been developed focusing on heritage documentation workflow [16-20], which were important references for the methodological planning of HBIM development for Casa de Vidro. Casa de Vidro's HBIM was developed considering the following steps: modeling planning; data acquisition; model elaboration; pathologies and damage recording; data management; management and process documentation.

\subsection{Modeling Planning}

The stage of planning should consider all the objectives and resources to be embraced [20]. The information modeling must be guided by the intended use of the HBIM model. Specific models can be elaborated for documentation, for evaluation of intervention proposals, for heritage management, among others. Therefore, information regarding the intended purpose of HBIM use should be inserted into the model to reflect its aim.

Within the scope of documenting Casa de Vidro, especially the current conditions of the building, a plan was established considering material and human resources. Coordinators and work teams were defined for the historical, landscape, and pathologies surveys, in addition to the team responsible for the HBIM. Thus, all documentation planning was designed as multidisciplinary work with the input of various specialists.

Considering the intended use, two distinct stages concerning historical data were idealized for Casa de Vidro's record within the HBIM. Generic modeling of the building was carried out in the first stage while, in the second stage, the model was refined with more detailed geometry, insertion of semantic information, and registering of the building phases. This process was conceived considering that all teams worked in parallel and considering that each teams' outcomes would be necessary to improve the model. 
In each stage, different forms of data acquisition were used to support the elaboration of the model, the record of pathologies, management, and documentation.

\subsection{Data Acquisition}

Data acquisition involves the capture of primary data on-site and the compilation of secondary sources of information [20]. According to [11,21], surveying existing buildings is a reverse engineering process, as it is developed after the building is established. It requires information from the actual building to then interpret the collected data and perform the modeling According to the authors, direct measurement methods are often unable to record the singularities of all elements accurately. Such methods require the direct contact of the operator with the object of study. Therefore, they are more suitable for less complex, small buildings [7].

Corroborating the measurement methods, [7] points out that digital photogrammetric techniques, including laser scanning, have enabled the collection of large amounts of information with greater precision and speed.

Data collection for Casa de Vidro included graphical data from various sources such as original architectural design documents, data regarding the changes made in the property, a topographic survey, direct measurements, laser scanning [22], and digital photogrammetry by stereo restitution. The buildings were characterized according to their function, use, constructive systems, and materials. These data were incorporated in the as-is version of the residence (see Section 3.3).

The remaining design, and the parti pris adopted by Lina Bo Bardi, were used in the as-designed version of the model. This version was enriched by historical and semantic data collected and analyzed by the heritage architecture specialists (see Section 3.3).

Pathologies and construction materials specialists documented the building damage through photographs and drawings. These data were represented in the damage map developed (see Section 3.4).

\subsection{Model Elaboration}

At this stage, the raw data collected on-site was turned into the desired end products [20]. It involved processing, analyzing, and manipulating information to generate outputs. Focusing on the architectural documentation of Casa de Vidro's buildings, an HBIM model was developed to record, preserve, and manage this heritage through an iterative process, improving information as new data was collected. HBIM intended to document the buildings and to subsidize a plan for their maintenance, operation, and conservation.

Several studies report the use of Autodesk Revit software for HBIM modeling [4,15,16,23,24]. Fewer studies report the use of Graphisoft ArchiCAD [25,26] and a custom modeling system focused on specific issues of heritage modeling [27]. To develop the HBIM integrated model of Casa de Vidro's set of buildings, Autodesk's software Revit and Navisworks were chosen. This choice was based, firstly, on the greater familiarity of the team involved in the modeling work with this tool, and secondly on the Brazilian architecture market, in which Autodesk is prominent.

During the first stage of modeling, data were collected using direct techniques (measuring tape) and was combined with pre-existing data, such as buildings records, documents regarding interventions, and a topography survey performed in the 1990s. The output of this first stage was a generic model of the architectural heritage.

In the second stage of modeling, indirect surveying techniques were used, including photographic and laser scanning. The photographic survey was processed into orthoimages. Laser scanning of the buildings was carried out [22]. From the obtained point cloud, views (plans, sections, etc.) were extracted to be used in the modeling, which, together with the orthoimages, allowed the development of a model with accurate geometry.

Figure 1 shows the location of the set of buildings extracted from the point cloud, with a $1 \times 1$ meter geometric grid to facilitate incorporation into the HBIM model. 


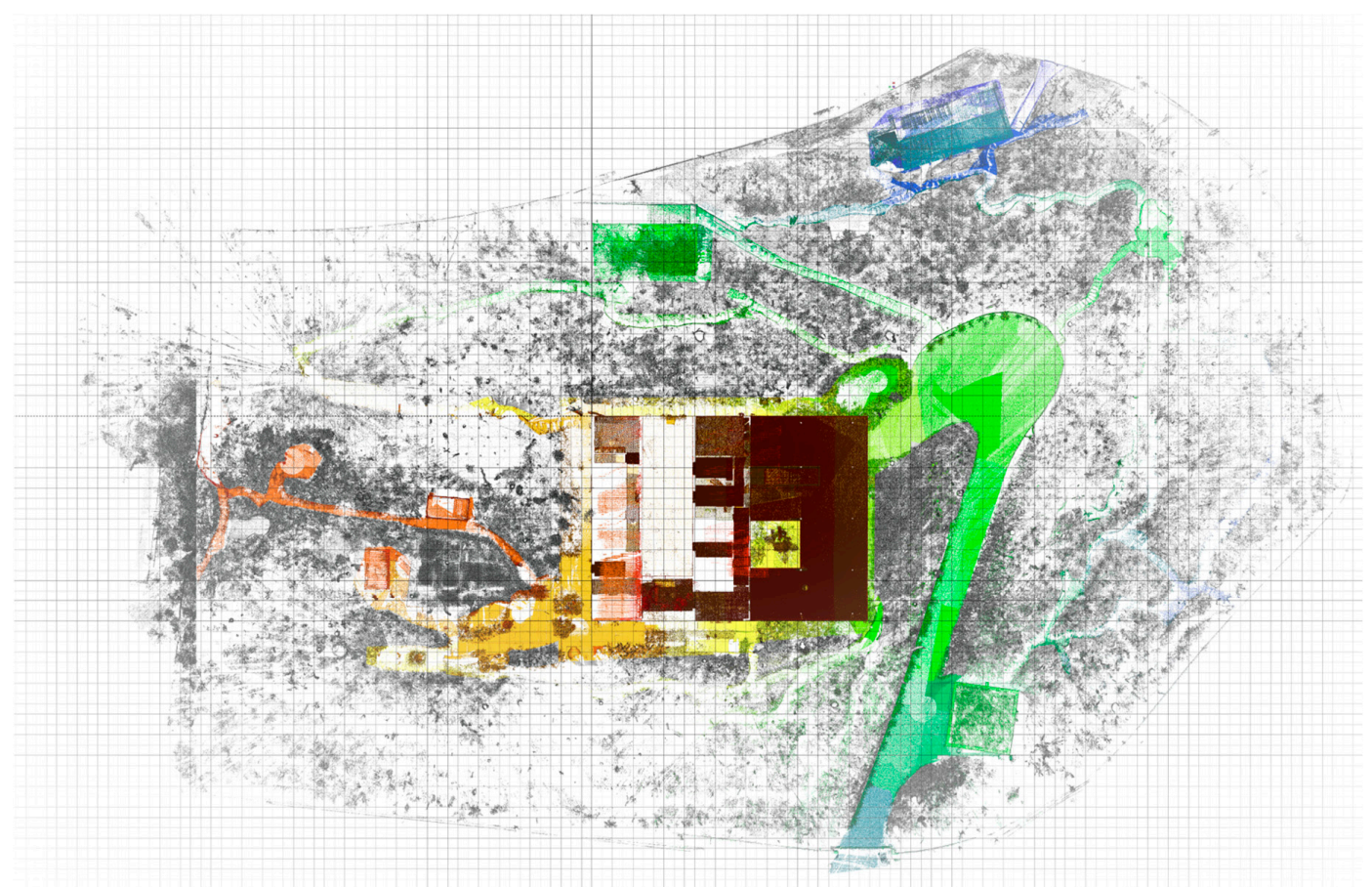

Figure 1. Aerial view of Casa de Vidro extracted from the point cloud (black: gardens with hidden canopies; other colors: buildings and drives, colored according to altimetric dimensions).

In a first approach, views generated from the point cloud were linked to the HBIM model to collate along with the model's geometry, which evidenced deviations. The imprecise elements were remodeled whenever necessary. During this process, the actual position of the columns, the curvature of the roofing slab, the dimensions of the floor slab, the glass facade glazing pockets, the access stair railing, the fireplace chimney, and other deviations were identified and adjusted. Deformations in the structure of the main staircase were also included in the model. Figures 2 and 3 illustrate the overlapping sections of the Revit model and point cloud.

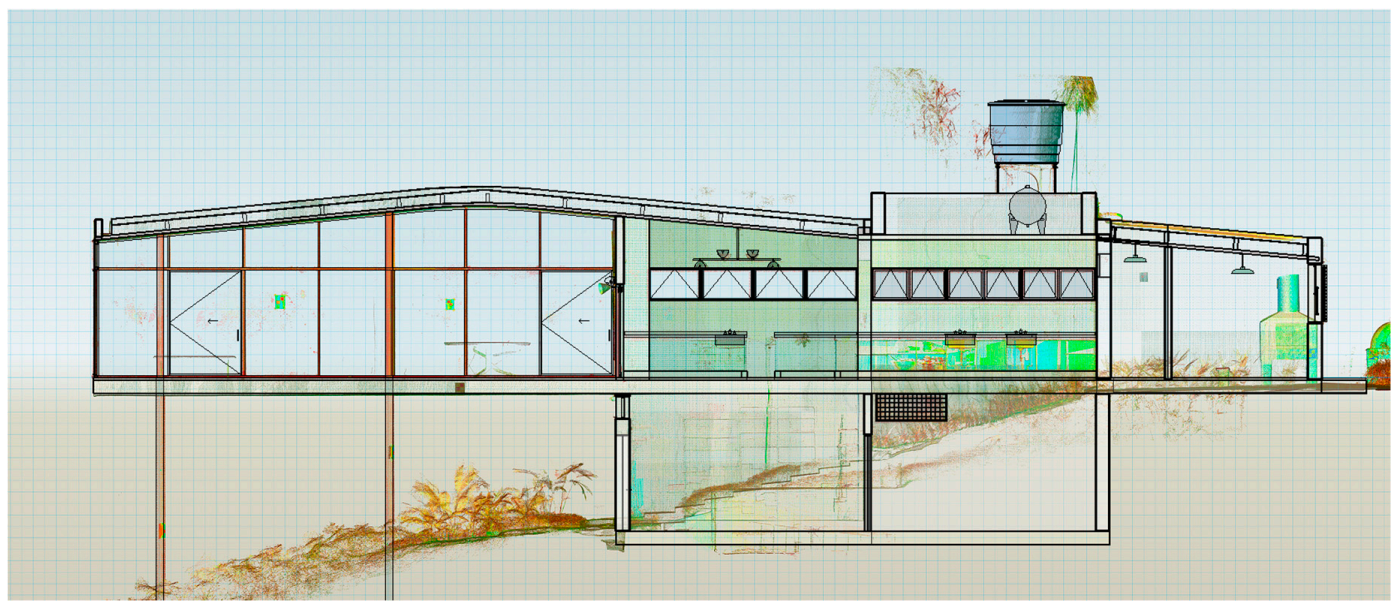

Figure 2. Longitudinal section of the Heritage Building Information Model (HBIM) overlapping with the point cloud image (in black: wire structure of the BIM model - other colors: representations from the point cloud). 


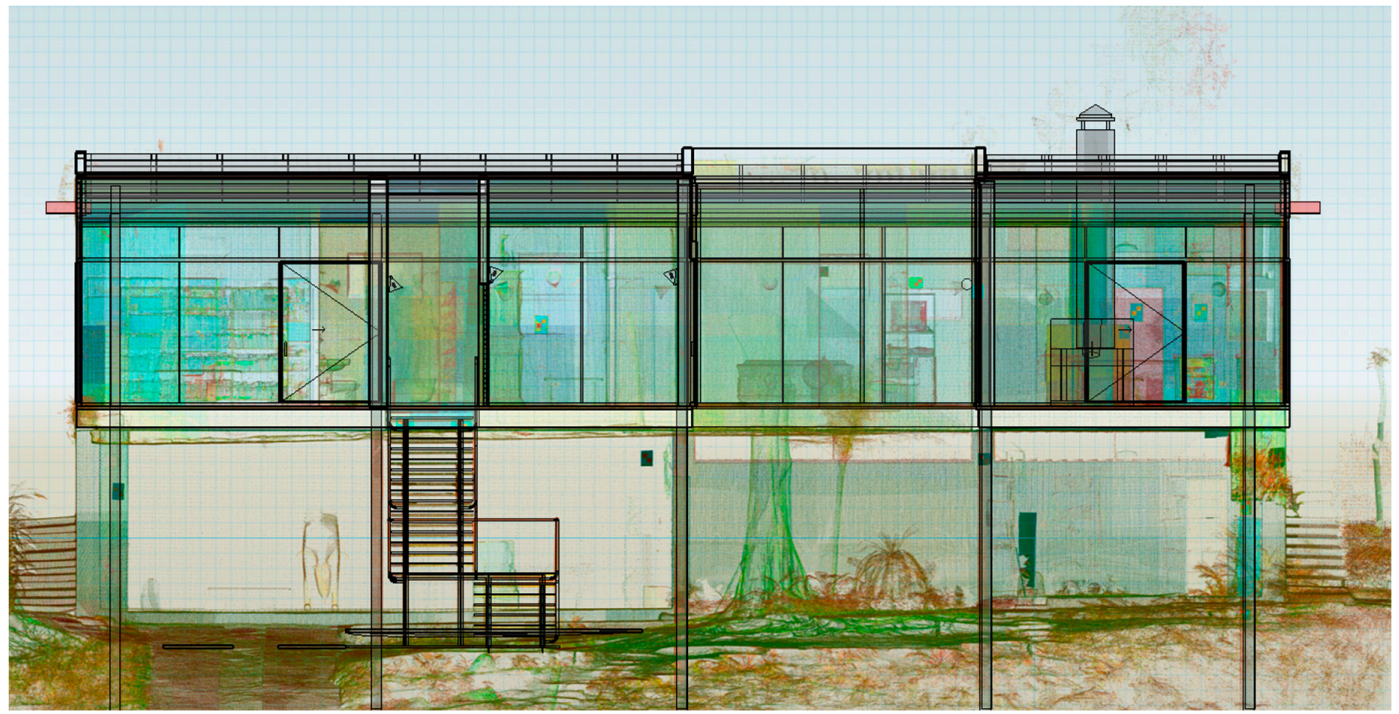

Figure 3. Cross section of the HBIM model overlapping with the point cloud image (in black: wire structure of the HBIM model; other colors: point cloud).

In a second approach, the segmented point cloud was linked to Revit software, serving as the basis for modeling the building elements. Shortly, two approaches were used for integrating the model into the point cloud. The first one was based on, the generation of orthoimages that were utilized for adjustments; and the second, a more direct one, based on importing the point cloud into the Revit software to serve as a baseline for 3D modeling. The latter proved to be more efficient. In this case, the segmented point cloud in Leica Cyclone software was emulated in Revit through the Leica Cloudworx plugin, enabling the modeling to be performed directly on the scanned point cloud. In Figure 4, we illustrate the process using Bo Bardi's architecture studio.



Figure 4. Point cloud imported to Revit used to model Bo Bardi's architecture studio.

During the development of the HBIM model, information from the "Historical Research" and "Structures, Materials, and Pathology" teams were incorporated. The "Historical Research" team identified different eras moments for the Casa de Vidro's modeling. Initially, it was considered that the 
modeling of the house could be done in three different ways: (i) according to the original design; (ii) as built (depicting its inauguration); (iii) and the current state of the building.

Based on the availability of information and records, we concluded that construction documentation was quite limited, preventing the "as-built" modeling. Even the design documentation presented substantial gaps, such as the disappearance of the structural detailing board, among others. Therefore, a mixed model was chosen, that use the information remaining from the projects, complemented with the building's records. We decided to model two phases of Casa de Vidro's life cycle, as designed and as built, here called the as-designed phase, and the current building (in 2017), called the as-is phase.

The as-designed model was developed from sketches by Lina Bo Bardi, technical drawings of building designs, records in the architect's workbook, invoices of building materials, photographs of the construction and the newly constructed building, as well as articles from architectural and construction magazines of the time. For example, by analyzing the notes on the construction and maintenance of the residence, the team identified that, in the late 1950s, due to the instability of the water supply system, a water tank was placed over the building. This information appears in the HBIM, Figure 5.

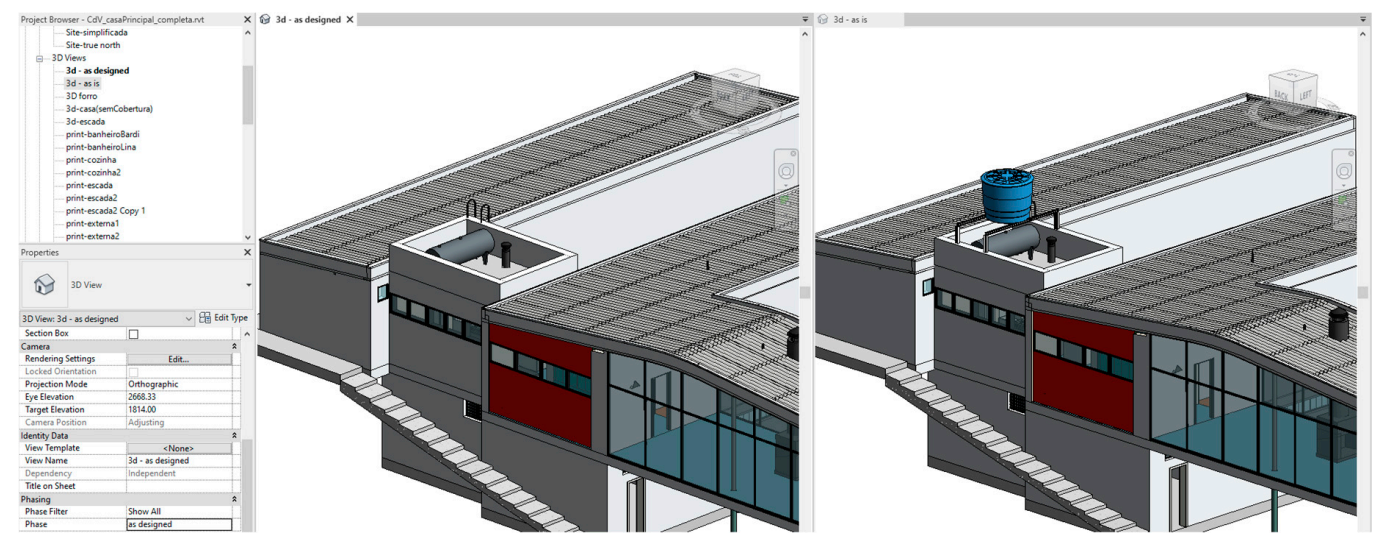

Figure 5. Building phases: as-designed and as-is.

There are also documents on structural design alternatives developed in Italy by Pier Luigi Nervi's office. These variations were not registered in the HBIM model. Perhaps, future research may incorporate such design alternative into the model the solutions studied.

The second phase of the modeled life cycle (as-is phase) depicted the current buildings (Casa de Vidro, Studio, Housekeeper House, and Garage), according to surveys carried out throughout 2017. It reflects the interventions made over the years, deformations and constructive pathologies.

It should be noted that, for the buildings in the complex other than the main house (i.e., Studio, Housekeeper House, and Garage), the models were not differentiated into two phases. They contemplate only the current situation of the buildings.

The modeling of the as-is phase was performed based on laser scanning and the generated point cloud, as well as on photogrammetry and orthomosaic data.

The Structures, Materials, and Pathology team provided data on the simulation of the structural model, which were inserted as a federated model of Casa de Vidro. The structural performance analysis was developed by a specialized consultant, using the TQS tool, a Brazilian structural software. Electric and hydraulic systems were not modeled. For the structural performance simulations, tests were performed to analyze the strength of the concrete floor slab and for qualitative and quantitative measurement of the internal reinforcement in the pillars. These analyses included assays and calculations. 
To verify clashes between the structural and architectural models, both were integrated using the Autodesk Navisworks tool. Compatibilization analysis pointed out modeling conflicts.

Regarding the semantic information added to the model, the historical surveys allowed the tracking of the concrete mixture used in the structures, despite not specifying the type of cement used (information not recovered). Based on data from the Structures, Materials, and Pathology team and the technical report, it was possible to add to the model information on the floor slab strength, which was around $30 \mathrm{MPa}$. That team also provided information on the damage map, which was added to the model and is presented below.

\subsection{Pathologies and Damages Documentation}

The pathological manifestations observed by the "Structures, Materials, and Pathology" team were initially documented through AutoCAD drawings, spreadsheets, and photographs. Subsequently, such information was inserted into the BIM models to generate an integrated documentation along with the other modeled information (graphical and semantic).

This documentation was based on the elaboration of damage maps in specific views of the HBIM models, adopting parametric elements hatched and modeled according to the type of pathology, being able to represent the form and the type of the pathological manifestation observed, Figure 6.

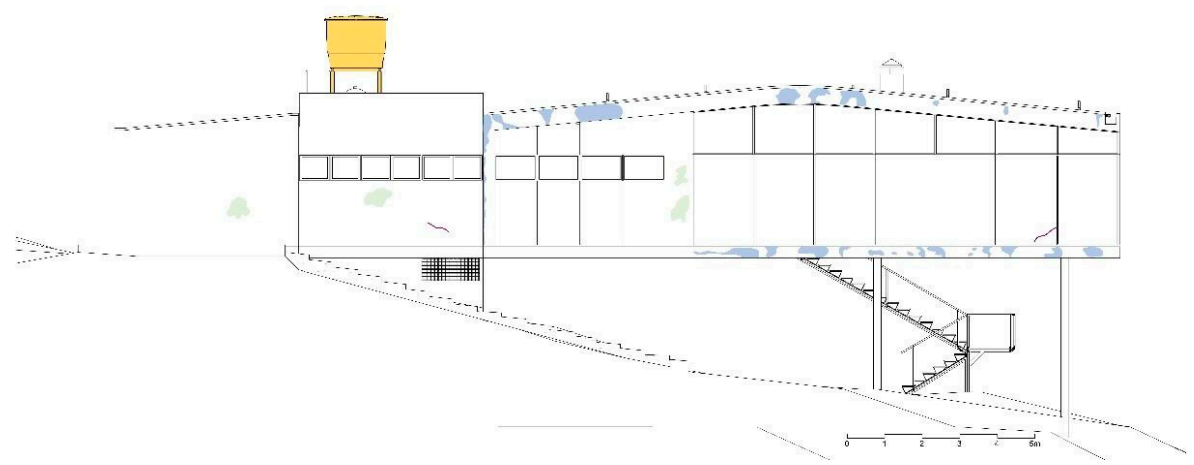

(a)

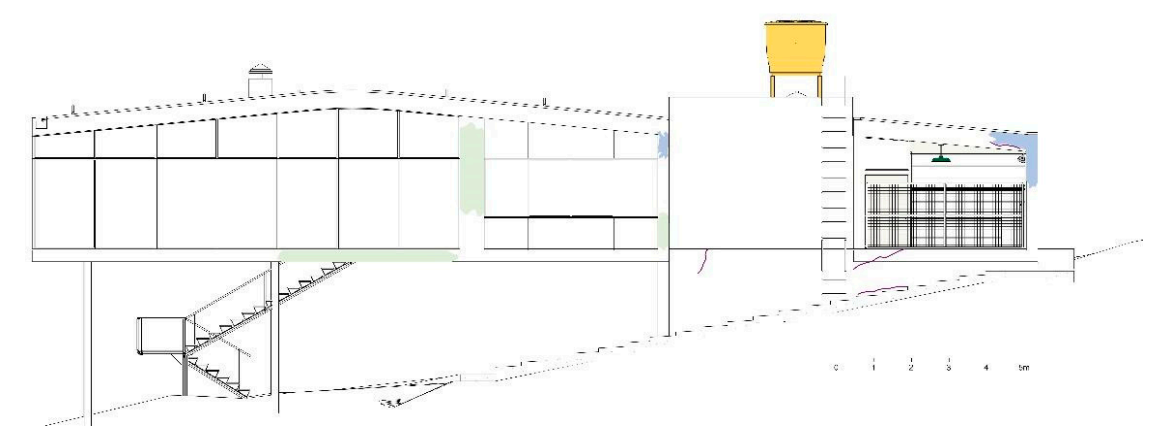

(b)

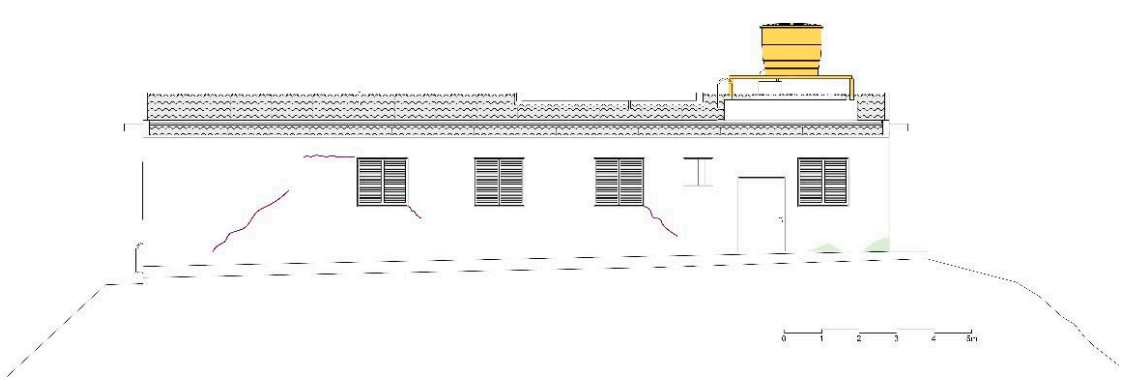

(c)

Figure 6. Views of Casa de Vidro's HBIM model illustrating the use of hatches for documenting pathological manifestations (a) and (b) side views; (c) back view. Source: Welen Martins. 
For that, two-dimensional detail elements (filled regions and polylines) were used in specific views of the HBIM model aiming to record and detail pathologies. This tool allowed the drawing of forms, approximating the model to the actual state of the building. Additionally, different hatches were used to visually distinguish the manifestations from the other components of the building.

The modeled pathologies received customized parameters to accommodate additional information to the model, aiming to collate information raised by the "Structures, Materials, and Pathology" team and to assist the maintenance management of the heritage assets. Various information regarding the pathologies, such as area, treatment technique, photographic record, cost survey, specific observations, and identifiers could be collected and stored. This data could be visualized as automatic captions in charts, detail views, tables, and reports. Different ways of inserting information concerning pathological manifestations into the model are under study including the creation of parametric families of pathologies.

\subsection{Data Management}

After processing the data, outputs must be indexed, stored, published, and distributed to ensure that they can be reused in the future [20]. In this sense, the HBIM model creates a record of historical research, as it encompasses both geometric data and metadata, improving data management.

The production and management of structured digital information are accomplished by a collaborative process that involves planning, managing the element with historical value, preventive maintenance, documentation, and research [6]. In the documentation of buildings of historical interest, the quality of the information is fundamental for the intended results. Low-quality, inaccurate, incomplete, or uncoordinated information leads to errors that may undermine the value and meaning of the heritage resource [6]. This documentation is composed of a multidisciplinary knowledge base, which, according to [28], is essential for the information integration between material and immaterial heritage. In this sense, the documentation of comprehensive and incremental knowledge of the built heritage represents a key activity for the development of HBIM.

The management of cultural heritage information should consider that several experts have contributed to data collection, the interpretation of information, and its processing in the form of an HBIM model. Understanding information within the model is critical to making decisions on future interventions, conservation, and management [6].

To develop the HBIM model of Casa de Vidro, the participation of a multidisciplinary team was critical for giving significance to the model elements and for the discussion of hierarchies of priorities and relevance to defining the precision and level of detail of each component. Also, this team provided historical, design, and material specifications to be incorporated into the BIM model.

To favor the collaboration among the teams, several interdisciplinary workshops were developed at Casa de Vidro's site. In addition, status update meetings for the presentation of preliminary results and integration between the teams were carried out within the research group "Arquibrás" at the IAU-USP.

To support the communication between teams and data storage, we adopted Google Drive cloud, with different permissions to each participant. Due to Google Drive limitations, the 150Gb point cloud file could not be stored in the cloud. It was stored on two computers at ILBPMB and IAU-USP. A backup copy was stored on an external hard drive.

For model development, Revit, Navisworks and Autocad tools were used in the 2017 version, and after converted, to be completed and delivered in the 2018 version. The incorporation of the point cloud in Revit made use of the Leica CloudWorx plugin. For structural simulation, TQS software was used. The consolidated model constitutes an essential collection of documents with accurate and up-to-date information on the set of buildings of ILBPMB head office and serves as a baseline for restoration and conversion projects and recording maintenance actions. Figure 7 shows the federated model containing the terrain, the Casa de Vidro building, Studio, Housekeeper House, and the Garage. 


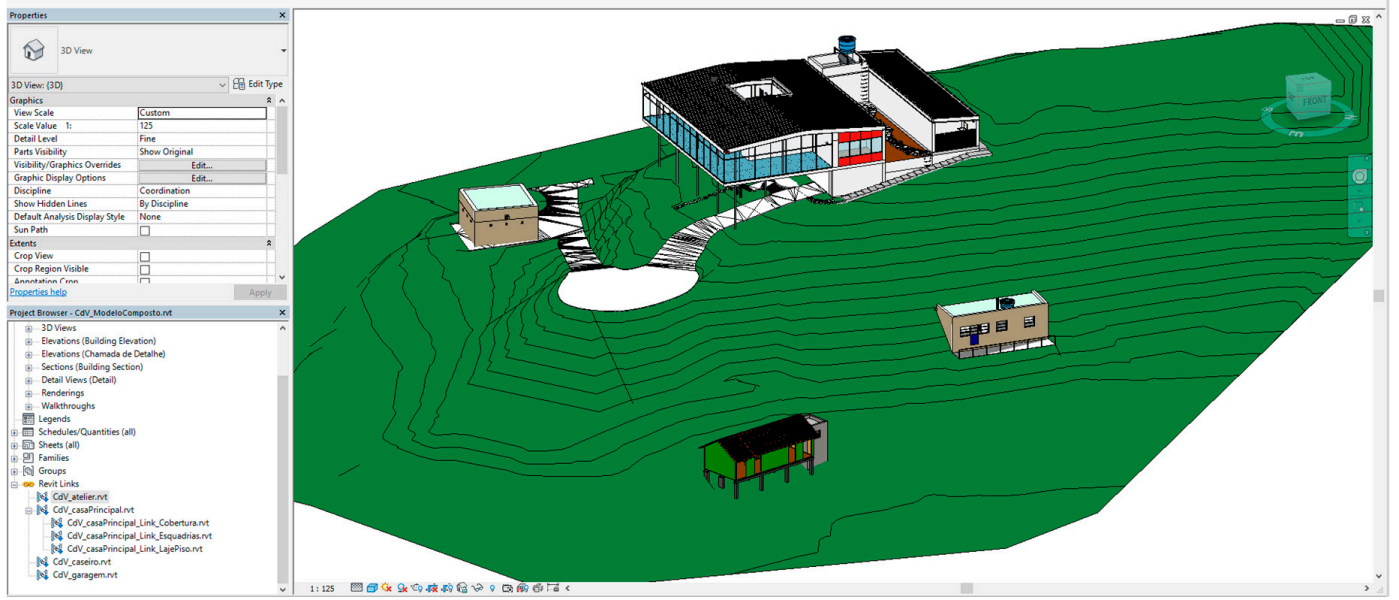

Figure 7. Federated model showing all buildings that make up the Lina Bo Bardi and Pietro Maria Bardi Institute (ILBPMB).

\subsection{Processes Documentation and Management}

The management and documentation of the processes aimed at analyzing various aspects of the documentation project itself, the procedures and resources used, and the quality of the product [20]. The experience of digital documentation and HBIM model development motivated the outline of an integrated flowchart of activities for collecting, processing, recording, and managing information that may be a baseline for future projects for documenting modernists buildings. Figure 8 presents a workflow of the complete documentation process.

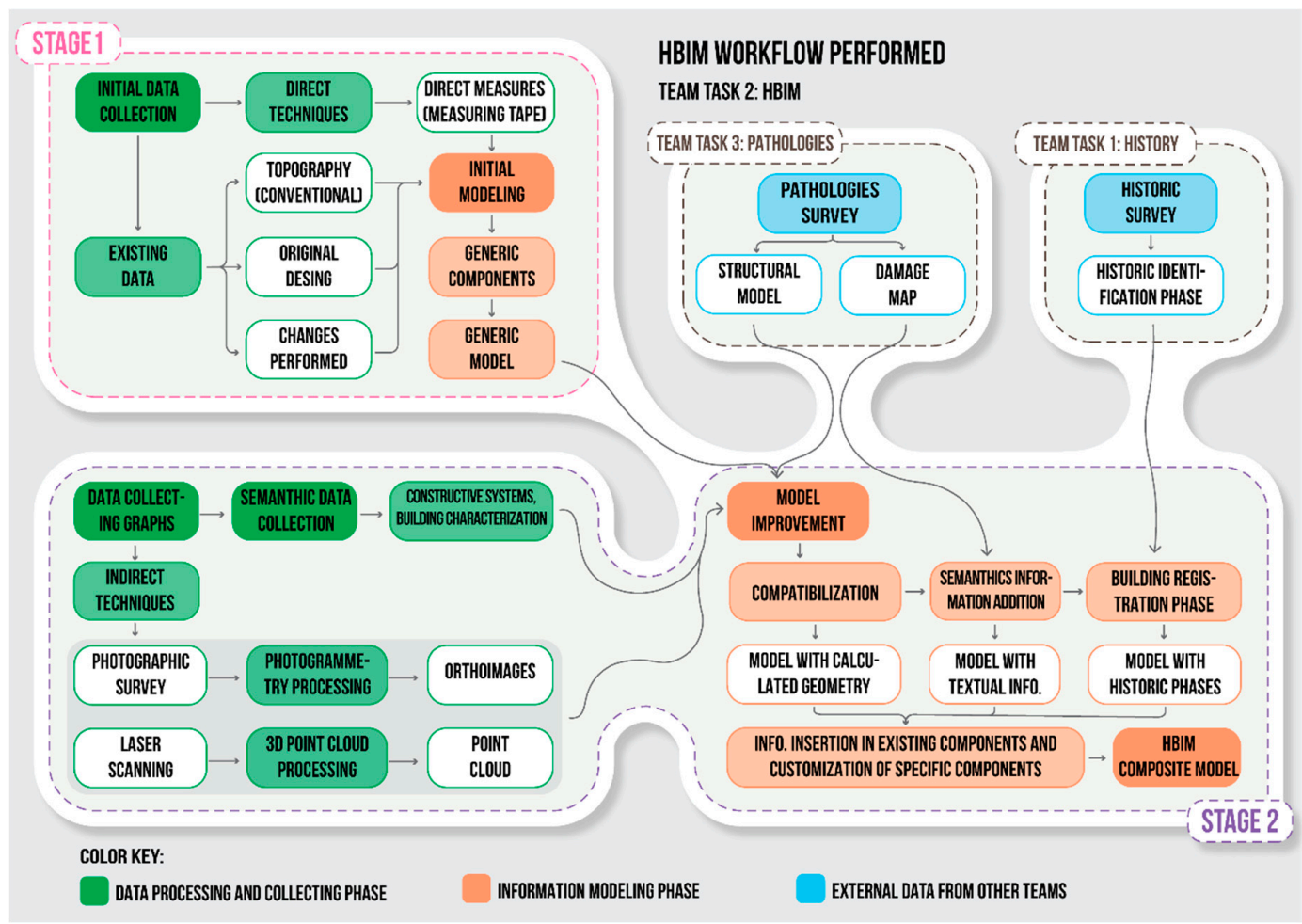

Figure 8. Casa de Vidro's HBIM workflow. 
In historical heritage buildings, it is necessary to consider different sources of information, including the original design, information derived from authentic documents and reports (letters, informal records, list of purchased materials, etc.), estimates with an acceptable degree of confidence, and information obtained by small-scale destructive assays applied to the materials and components of the building. It is necessary to consider the reliability of each of these sources at every stage of modeling as well as the costs, hazards, and benefits of each source.

The developed Casa de Vidro model is not an entirely accurate inventory since the lack of information and limitations of the modeling tools decrease the accuracy of the outputs. Yet, the developed HBIM model is a relevant record, and potentially the most accurate digital model of Lina Bo's Casa de Vidro ever made, including accurate geometric information, structural simulations, damage map recording, and current constructive pathologies, in addition to historical information.

For the building manager, it is essential to communicate the reliability level of the digital model and its elements. Noteworthy, for the HBIM development, some information relied on estimates elaborated by experts and/or were based on incomplete information from the original design and the building records. Thus, is the HBIM model includes information from different categories, with varying levels of accuracy. Focusing on the preservation and conservation of the building, new attributes could be continuously added to the modeled components, such as the dates of replacement/insertion of new materials and components in the building, technical details of the materials, and others. A release version of the HBIM model is available online for students and architecture professionals (Glass House model on Autodesk A360: https://arquitec.iau.usp.br/projetos/casa-de-vidro-projeto-getty).

\section{Final Considerations}

The use of HBIM for purposes of documentation of Brazilian modernist architectural heritage is still very restricted. In this article, we present the procedures adopted to develop an HBIM of Casa de Vidro, emphasizing the documentation of the building's current state of conservation and subsidizing the planning of preservation, maintenance, and publicizing actions.

Comparing the BIM model with the point cloud generated by 3D scanning made it possible to adjust the model to obtain better geometric consistency. One of the greatest benefits of the point cloud generated through laser scanning was its high accuracy that allowed us to build a model with precise geometry.

The model presents variable precision related to the technical-constructive detailing. For the elements whose materials were well documented or were surveyed during the specialist's inspections, the model was parameterized to reflect these details. Some items, depending on their importance for the construction and the availability of information, were detailed accordingly.

In Casa de Vidro's architectural model, elements and constructive components were represented as accurately as possible. However, this effort faced some difficulties related to the lack of accurate information in some cases, the absence of appropriated models of components, the limits of the modeling solutions used to incorporate wearing, deformation and so on. Likewise, [4] pointed out some challenges faced during the elaboration of the model, given the absence of families of components and $[16,23]$ adverted that the level of development (LOD) of the elements of the HBIM modeling was not homogeneous.

Revit, proved to be suitable for the documentation of modernist architecture, as it contains features that support the virtual reconstruction of most elements. However, as a tool originally developed for designing new buildings, it faces challenges when recording imperfections and deformations. It is still considered of potential use for recording other modernist buildings of historical interest.

The HBIM developed for Casa de Vidro allows architecture, conservation, and restoration professionals to easily and quickly access integrated information on projects and the current conditions of the buildings, with good precision for the most important elements, contributing to the planning of maintenance and restoration actions. 
The conservation of a building of historical interest is based on decisions [29], and it is essential to mention that this parametric database must be updated with every intervention, change or discovery in order to maintain a precise and dynamic register of the buildings of the Casa de Vidro's complex.

As technology advances or discoveries concerning the original project emerge, it is convenient to adjust the model to enhance its fidelity to the actual built state, according to the life-cycle phases.

In short, protection, conservation, restoration, monitoring, management, and recording of cultural objects and physical preservation can be supported by documentation in HBIM.

In addition to the model itself, another contribution of this work is the report of the HBIM implementation process. As pointed out by [30], documentation is needed for conservation, but also for public awareness. To that end, the authors add that it is convenient to have an interactive multimedia environment that allows dialogue between specialists and non-specialists.

In this sense, the use of interactive multimedia systems can foster interest in historic buildings, supporting diffusion and awareness of cultural assets. In the future, it is possible to transpose the information contained in the model to more appropriate systems for interaction with lay users, promoting actions to disseminate the consolidated knowledge that the HBIM provides.

Author Contributions: Conceptualization, A.R.M.C. and M.M.F.; methodology, A.R.M.C. and M.M.F.; investigation, A.R.M.C. and, M.M.F and J.C.F.J.; resources, A.R.M.C.; writing-original draft preparation, A.R.M.C. and J.C.F.J.; writing-review and editing, A.R.M.C., M.M.F. and J.C.F.J.; supervision, M.M.F.; project administration, M.M.F.

Funding: This research was funded by the Getty Foundation under the grant "Keeping It Modern" 2016-July.

Acknowledgments: The authors thank: Renato S. Anelli, a researcher in the fields of theory and history of architecture and general coordinator of Casa de Vidros's conservation and restoration project, who collaborated providing historical information and assigning significance to the architectural elements of the building. Ana Lúcia Cerávolo, a specialist in architectural heritage and assistant coordinator to the conservation project, and Aline Sanches Corato, who works in the field of history of architecture and is an expert on Lina Bo Bardi, who were also part of the team. In the areas of structures and construction technology, Adriano Rossignolo coordinated the team with the collaboration of Osny Pelegrino, both experts' engineers at construction materials. The engineer and doctor Bruno de Santis and engineer Alexandre Rosin Pereira, who worked on the survey of pathologies in the buildings that make up the ILBPMB, as well as the Eng. Ricardo Couceiro Bento, consultant, who developed the analyses and simulations of the Casa de Vidro's structural system performance. These colleagues provided information on building materials, structural solutions, a map of damage, and pathologies recorded in the HBIM model. In the area of landscaping, Luciana Schenck coordinated the team that included Lígia Paludetto. These colleagues carried out the accurate cataloging of the gardens integrating the ensemble and carried out a management plan for the species present in the garden. The team from the University of Ferrara, Diaprem, responsible for laser scanning (Scaner Leica) and who provided training on cloud point manipulation for the authors. Architect Welen Martins, responsible for inputting information regarding pathologies in Casa de Vidro's model. Camila Manoel Crnkovic, who revised the English language. CNPq for the research productivity grant, process 306998/2018-1.

Conflicts of Interest: The authors declare no conflict of interest.

\section{References}

1. Anelli, R.; Camacho, S. Casas de Vidro; Romano Guerra: São Paulo, Brazil, 2018.

2. Cuperschmid, A.R.M.; Cerávolo, A.L.; Grachet, M.G.; Franco Júnior, J.C.; Fabricio, M.M. Casa de Vidro: BIM e Gestão do Patrimônio Histórico Arquitetônico. Cad. PROARQ 2018, 30, 177-198.

3. Mindlin, H. Arquitetura Moderna no Brasil; Aeroplano/IPHAN: Rio de Janeiro, Brazil, 2000.

4. From Survey to HBIM for Documentation, Dissemination and Management of Built Heritage: The Case Study of St. Maria in Scaria d'Intelvi. In Proceedings of the 2013 Digital Heritage International Congress (DigitalHeritage), Marseille, France, 28 October-1 November 2013.

5. Del Giudice, M.; Osello, A. BIM for Cultural Heritage. In Proceedings of the International Archives of the Photogrammetry, Remote Sensing and Spatial Information Sciences-ISPRS Archives, Strasbourg, France, 2-6 September 2013; Volume XL-5/W2, pp. 225-229.

6. Historic England. BIM for Heritage: Developing a Historic Building Information Model; Historic England: Swindon, UK, 2017. 
7. Groetelaars, N.J. Criação de Modelos BIM a partir de "Nuvens de Pontos": Estudo de Métodos e Técnicas Para Documentação Arquitetônica. Doctoral Thesis, Universidade Federal da Bahia, Salvador, Brazil, 7 April 2015; p. 372.

8. McGovern, E.; Murphy, M.; Pavia, S. Historic building information modelling (HBIM). Struct. Surv. 2009, 27, 311-327.

9. Murphy, M.; McGovern, E.; Pavia, S. Historic Building Information Modelling_Adding intelligence to laser and image based surveys of European classical architecture. ISPRS J. Photogramm. Remote Sens. 2013, 76, 89-102. [CrossRef]

10. Brusaporci, S.; Maiezza, P.; Tata, A. A framework for architectural heritage hbim Semantization and development. ISPRS-Int. Arch. Photogramm. Remote Sens. Spat. Inf. Sci. 2018, 42, 179-184. [CrossRef]

11. García-Valldecabres, J.; Pellicer, E.; Jordan-Palomar, I. BIM Scientific Literature Review for Existing Buildings and a Theoretical Method: Proposal for Heritage Data Management Using HBIM. Constr. Res. Congr. 2016, 2016, 2228-2238.

12. Wu, T.C.; Lin, Y.C.; Hsu, M.F.; Zheng, N.W.; Chen, W.L. Improving traditional building repair construction quality using historic building information modeling concept. ISPRS-Int. Arch. Photogramm. Remote Sens. Spat. Inf. Sci. 2013, 40, 691-694. [CrossRef]

13. Mansir, D.; Muhammad, J.A.; Kasim, N. Reviewing the Need for HBIM in the conservation of Heritage Building. Soc. Sci. 2016, 11, 2777-2782.

14. Arayici, Y.; Mahdjoubi, L.; Counsell, J.; Nagy, G.; Hawas, S.; Dweidar, K. (Eds.) Heritage Building Information Modelling, 1st ed.; Routledge: London, UK, 2017; ISBN 9781315628011.

15. Di, Y.; Wu, C. Research on the BIM of the Stone Building for Heritages Conservation. In Proceedings of the 2011 3rd International Conference on Education Technology and Computer (ICETC 2011), Lushan, China, 5-16 July 2011; pp. 1488-1491.

16. Pauwels, P.; Bod, R.; Di Mascio, D.; De Meyer, R. Integrating building information modelling and semantic web technologies for the management of built heritage information. Digit. Herit. Int. Congress (DigitalHeritage) 2013, 1, 481-488.

17. Moreira, A.; Quattrini, R.; Maggiolo, G.; Mammoli, R. Hbim methodology as a bridge between Italy and argentina. ISPRS-Int. Arch. Photogramm. Remote Sens. Spat. Inf. Sci. 2018, 42, 715-722. [CrossRef]

18. Quattrini, R.; Pierdicca, R.; Morbidoni, C. Knowledge-based data enrichment for HBIM: Exploring high-quality models using the semantic-web. J. Cult. Herit. 2017, 28, 129-139. [CrossRef]

19. Jordan-Palomar, I.; Tzortzopoulos, P.; García-Valldecabres, J.; Pellicer, E. Protocol to Manage Heritage-Building Interventions Using Heritage Building Information Modelling (HBIM). Sustainability 2018, 10, 908. [CrossRef]

20. Amorim, A. Methodological Aspects of Architectural Documentation. Geoinform. FCE CTU 2011, 6, 34-39. [CrossRef]

21. Dezen-Kempter, E.; Soibelman, L.; Chen, M.; Filho, A.V.M. escaneamento 3D a laser, fotogrametria e modelagem da informação da construção para gestão e operação de edificações históricas. Gestão Tecnol. Proj. 2015, 10, 113. [CrossRef]

22. Balzani, M.; Maietti, F.; Rossato, L. 3D data processing toward maintenance and conservation. The integrated digital documentation of casa de vidro. ISPRS-Int. Arch. Photogramm. Remote Sens. Spat. Inf. Sci. 2019, 42, 65-72. [CrossRef]

23. Biagini, C.; Capone, P.; Donato, V.; Facchini, N. Towards the BIM implementation for historical building restoration sites. Autom. Constr. 2015, 71,74-86. [CrossRef]

24. Tolentino, M.M.A. A Utilização do HBIM na Documentação, na Gestão e na Preservação do Patrimônio Arquitetônico. In Proceedings of the XX Congreso de la Sociedad Iberoamericana de Gráfica Digital, Iberoam, Buenos Aires, Argentina, 9-11 November 2016; pp. 510-518.

25. Canuto, C.L. Modelo BIM e Proposta de Intervenção do Palácio Gustavo Capanema, Rio de Janeiro, RJ: Pela Preservação Digital da Arquitetura Moderna. Master's Dissertation, Universidade Federal do Rio de Janeiro, Rio de Janeiro, Brazil, 2017.

26. Paiva, R.; Diógenes, B.C. Futuro do Pretérito: BIM e Documentação Digital da Arquitetura Moderna em Fortaleza. In Proceedings of the Encontro Brasileiro de Tecnologia de Informação e Comunicação na construção, Porto Alegre, Brazil, 4-6 November 2015; Volume 7. 
27. Fassi, F.; Fregonese, L.; Adami, A.; Rechichi, F. Bim system for the conservation and preservation of the mosaics of san marco in venice. ISPRS-Int. Arch. Photogramm. Remote Sens. Spat. Inf. Sci. 2017, XLII-2/W5, 229-236. [CrossRef]

28. Canuto, C.L.; Moura, L.R.; Salgado, M.S. Tecnologias digitais e preservação do patrimônio arquitetônico: Explorando alternativas. PARC Pesqui Arquitetura Construção 2016, 7, 252-264. [CrossRef]

29. Eppich, R.; Chabbi, A. Recording, Documentation, and Information Management for the Conservation of Heritage Places: Illustrated Examples; Donhead: Shaftesbury, UK, 2007; Volume 2, ISBN 978-0-89236-946.

30. Haddad, N.A.; Akasheh, T.S.; Lerma, J.L.; Khresat, B.R. Towards a Risk Management and Conservation Plan for the Djin Blocks at the World Heritage Site of Petra, Jordan: The Case of Djin Block No. 9. Conserv. Manag. Archaeol. Sites 2015, 17, 175-191. [CrossRef]

(C) 2019 by the authors. Licensee MDPI, Basel, Switzerland. This article is an open access article distributed under the terms and conditions of the Creative Commons Attribution (CC BY) license (http://creativecommons.org/licenses/by/4.0/). 